\title{
Kinase inhibitor Sorafenib modulates immunosuppressive cell populations in a murine liver cancer model
}

\author{
Mengde Cao ${ }^{1}$, Yiling Xu' ${ }^{1}$, Je-in Youn ${ }^{2}$, Roniel Cabrera ${ }^{1}$, Xiaokui Zhang ${ }^{3}$, Dmitry Gabrilovich², David R Nelson ${ }^{1, *}$ \\ and Chen $\mathrm{Liu}^{3, *}$
}

Accumulating evidence suggests that regulatory T cells (Tregs) and myeloid-derived suppressor cells (MDSC) are elevated in cancer patients and tumor-bearing hosts, and that depletion of Tregs and MDSC may enhance the anti-tumor immunity of the host. Sorafenib, a novel multi-kinase inhibitor, is approved for the treatment of several human cancers, including advanced hepatocellular carcinoma (HCC). Sorafenib is believed to inhibit tumor growth via anti-angiogenesis, cell cycle arrest, and inducing apoptosis. However, the impact of Sorafenib on immune cell populations in tumor-bearing hosts is unclear. In this report, we show that Tregs and MDSC are increased in the spleens and bone marrows of the BALB/C mice with liver hepatoma. The increase in Tregs and MDSC was positively correlated with tumor burden. Treatment of Sorafenib not only inhibited HCC cell growth in mice but also significantly decreased the suppressive immune cell populations: Tregs and MDSC. In conclusion, our study strongly suggests that Sorafenib can enhance anti-tumor immunity via modulating immunosuppressive cell populations in the murine liver cancer model.

Laboratory Investigation (2011) 91, 598-608; doi:10.1038/labinvest.2010.205; published online 14 February 2011

KEYWORDS: hepatocellular carcinoma; kinase inhibitor; myeloid-derived suppressor cells; regulatory T cells; Sorafenib

Hepatocellular carcinoma (HCC) is one of the most common malignant tumors worldwide. Most patients present in late stages of the disease when surgical resection is not feasible, which leads to dismal clinical outcomes. The annual mortality rate is almost equal to the annual incidence, which is approximately 600000 patients. ${ }^{1,2}$ Radiation therapy and chemotherapy are generally not very effective for HCC. Therefore, developing effective new strategies to target liver cancer is urgently needed. Many studies have investigated immune responses in patients with $\mathrm{HCC}^{3-6}$ and have explored approaches to harness anti-tumor immunity. ${ }^{3,7-10}$ Immunotherapy for liver cancer has also been actively investigated, and some clinical trials have been reported. ${ }^{11}$ Attention has mainly focused on the induction of HCC tumor-specific immunity by introducing tumor-associated antigens (TAAs) ${ }^{12-14}$ Among these TAAs, alpha-fetal protein and glypican-3 have generated significant interest. ${ }^{15-17}$ Both proteins are expressed during embryogenesis, but are silent in most adult tissues. These two proteins are valuable for HCC diagnosis and they have the potential to be target antigens for immunotherapy. Although evidence of immune response to these two antigens in HCC patients has been demonstrated, eliciting anti-tumor immunity using these two antigens is still not robust. ${ }^{18-21}$ One of the potential explanations is that the expression of these two proteins during embryogenesis might have caused immune tolerance in adults. However, it is still unclear how the host immunosurvillence mechanisms interact with HCC to allow tumor to grow. Recently, many studies have suggested the presence of suppressor immune cells that have an important role in immune homeostasis and cancer development/ progression. $^{22}$

Several studies, including ours, have shown that development of HCC is associated with a number of immunosuppressive mechanisms. ${ }^{5,23-25}$ Two groups of cells are implicated as main mediators of immune suppression in

\footnotetext{
Department of Medicine, University of Florida, Gainesville, FL, USA; ${ }^{2}$ Department of Immunology, H. Lee Moffitt Cancer Center, Tampa, FL, USA and

${ }^{3}$ Department of Pathology, Immunology and Laboratory Medicine, University of Florida, Gainesville, FL, USA

Correspondence: Dr C Liu, MD, PhD, Department of Pathology, Immunology and Laboratory Medicine, University of Florida, 1600 SW Archer Rd, PO Box 100275 , Gainesville, FL 32610, USA.

E-mail: Liu@pathology.ufl.edu

${ }^{*}$ These authors share senior authorship.
}

Received 28 April 2010; revised 17 October 2010; accepted 9 November 2010 
cancer: regulatory T cells (Tregs) and regulatory myeloid cells -myeloid-derived suppressor cells (MDSC). MDSC is a heterogeneous population of cells in tumor-bearing mice and cancer patients that have been shown to inhibit T-cell responses. ${ }^{26-29}$ Upregulation of Tregs and MDSC has been demonstrated in patients with HCC. ${ }^{25,26,30}$ MDSC (identified as $\mathrm{CD} 11 \mathrm{~b}^{+} \mathrm{Gr}-1^{+}$cells) have also been shown to accumulate in the spleens, bone marrows, and tumor tissues in tumorbearing mice. ${ }^{28}$ It has been suggested that MDSC suppresses specific cellular response to cancer cells. ${ }^{26} \mathrm{~A}$ recent report has also highlighted that MDSC can inhibit NK cells in HCC patients. ${ }^{30}$ It is possible that modulation of these cells may offer a new avenue for immunotherapy against cancer. Interestingly, current chemotherapy might already take advantage of this immunoregulatory mechanism. One recent report has shown that the kinase inhibitor, sunitinib, is capable of reversing the accumulation of the suppressive cell populations: MDSC and Tregs, which are potential new mechanisms for this chemotherapy. ${ }^{31}$ Sorafenib, another multiple kinase inhibitor, has recently been approved as the first agent for advanced liver cancer therapy. Besides its cell growth inhibitory activity, the precise mechanisms by which Sorafenib suppresses HCC in patients remain to be defined.

To understand the immunoregulation in HCC, to define the mechanisms of therapeutic anti-HCC agents, and to develop more effective immunotherapy, it is essential to have a robust and reliable small-animal model. Genetically engineered mouse models and xenograft liver cancer models are excellent tools to study the intracellular signaling pathways, altered in hepatocarcinogenesis, and to evaluate therapeutic efficacy for anticancer molecules. However, models that can be used for studying immunoregulation in HCC are limited. Recently, Gonzalez-Carmona et al ${ }^{32}$ have described an immunocompetent murine model using mouse HCC cell line Hepa129 and the $\mathrm{C} 3 \mathrm{H} / \mathrm{HeNcrl}$ mice for investigating anti-tumor dendritic cells.

In this report, we describe a robust mouse liver cancer model in a commonly used immunocompetent $\mathrm{BALB} / \mathrm{c}$ mouse strain. Immune responses and suppressor cells form a complex network in this HCC cancer-bearing mouse model. Moreover, we have shown that Sorafenib is capable of suppressing HCC progression in mice and downregulating Tregs and MDSC, which suggests a novel anti-HCC mechanism in this tumor model.

\section{MATERIALS AND METHODS Tumor Cell Line and Cell Culture}

A mouse liver hepatoma cell line BNL 1ME A.7R.1 (referred as 1MEA in this study), was obtained from American Type Culture Collection (ATCC), and maintained in Dulbecco's minimal essential medium (DMEM) supplemented with $10 \%$ heat-inactivated $\left(56^{\circ} \mathrm{C}, 30 \mathrm{~min}\right)$ fetal bovine serum (FBS) (GIBCO) and $100 \mathrm{U} / \mathrm{ml}$ penicillin, $100 \mu \mathrm{g} / \mathrm{ml}$ streptomycin (Cellgro), L-glutamine $(2 \mathrm{mM})$ in humidified atmosphere of
$5 \% \mathrm{CO}_{2}$ at $37^{\circ} \mathrm{C}$. This tumor cell line was developed from $\mathrm{BALB} / \mathrm{c}$ mouse. ${ }^{33}$

\section{Mice and Tumor Injection}

$\mathrm{BALB} / \mathrm{c}$ mice (6-8 weeks of age) were obtained from the Jackson Laboratory. Mice were kept in pathogen-free conditions and handled in accordance with the requirements of the Institutional Guideline for Animal Experiments. The right flanks of $\mathrm{BALB} / \mathrm{c}$ mice were injected subcutaneously (s.c.) with $5 \times 10^{6} 1 \mathrm{MEA}$ cells in $100 \mu \mathrm{l}$ of phosphate-buffered saline (PBS). At the end point of the experiments, mice were sacrificed and spleens were collected. Tumors were separated from mice and were measured. Tumor size was indicated as weight $(\mathrm{mg})$. Representative tumor tissues were carefully excised and surface blood was removed by rinsing in cold PBS, then fixed in 10\% neutral formalin, and processed for histology staining, or prepared into single cells and stained with fluorescence-conjugated antibodies for flow cytometry analysis.

\section{Flow Cytometric Analysis}

Splenic cells were obtained by pressing splenic tissue or lymph node tissue, respectively, through a Nylon Cell Strainer of $40 \mu \mathrm{m}$ mesh (BD Falcon). Bone marrow cells were collected by flushing femurs and tibias with cold $1 \times$ PBS in a syringe with a 27 -gauge needle. Tumors were prepared as described above to obtain single-cell suspensions. Red blood cells were removed using red blood lysing buffer (Sigma). To decrease nonspecific binding of immunoglobulins, cells were incubated for $30 \mathrm{~min}$ with anti-CD16/32 (Fc block). The resulting cells were stained with fluorescence-conjugated antibodies anti-Gr-1, anti-CD11b, anti-CD3, anti-CD4, antiCD25 (BD Pharmingen), and anti-FOXP3 (eBioscience). After washing with PBS twice, at least 200000 events were collected and analyzed on a FACSCalibur system with CELLQuest software (Becton Dickinson) for each analysis. The data were expressed as a proportion of positive cells (compared with cells stained with an irrelevant control antibody).

\section{CD11b ${ }^{+}$Cell Functional Assays}

$\mathrm{CD}_{11 \mathrm{~b}^{+}}$cells, with purity of more than $90 \%$, were positively selected from splenocytes derived from tumor-free and tumor-bearing mice, by using CD11b microbeads (Miltenyi Biotec), respectively. The $\mathrm{CD} 11 \mathrm{~b}^{+}$-depleted splenocytes were used as responders, and placed in triplicates into a U-bottom 96-well plate $\left(1 \times 10^{5} /\right.$ well $)$, and cocultured with $\mathrm{CD} 11 \mathrm{~b}^{+}$ cells (as stimulators) at different ratios in the presence of anti-CD3 $(5 \mu \mathrm{g} / \mathrm{ml})$ for $48 \mathrm{~h}$. At $18 \mathrm{~h}$ before collecting, cells were pulsed with $\left[{ }^{3} \mathrm{H}\right]$ thymidine $(1 \mu \mathrm{Ci} /$ well; Perkin-Elmer). $\left[{ }^{3} \mathrm{H}\right]$ thymidine uptake was counted using a liquid scintillation counter and expressed as the mean counts per minute. 


\section{Sorafenib Treatment In Vivo}

Sorafenib (Nexavar, $200 \mathrm{mg} /$ tablets) was dissolved in Cremophor EL/95\% ethanol (termed as solvent) (50:50; Sigma), prepared stock solution at $6 \mathrm{mg} / \mathrm{ml}$, and stored in $-20^{\circ} \mathrm{C}$ for in vivo study. After 2 weeks from tumor cells challenging, mice were divided into two groups $(10$ mice/ group) and orally fed Sorafenib at $0.6 \mathrm{mg} / 100 \mu \mathrm{l} / \mathrm{mouse}$ (30 mg/kg, once daily), or $100 \mu \mathrm{l}$ Cremophor EL $/ 95 \%$ ethanol (control group), respectively, by gavage for 2 weeks. At the end point of experiments, mice were killed; tumors and spleens were dissociated and weighed, and femurs and tibias were collected. Splenocytes, bone marrow cells, and single tumor cells were prepared for further analysis.

\section{Immunohistochemistry Analysis of Tumor-Infiltrating Lymphocytes}

Tumor tissues were immediately removed from the mice following $\mathrm{CO}_{2}$ asphyxiation and fixed in $10 \%$ formalin for $4 \mathrm{~h}$. Subsequent tissue processing, including sectioning and staining, was performed using services provided by the University of Florida's Molecular Pathology and Immunology Core. Briefly, sections obtained through formalin-fixed samples were paraffin-embedded, cut, and collected $100 \mu \mathrm{m}$ apart, then stained with antibodies to CD4, CD8, and CD25.

To obtain tumor-infiltrating lymphocytes (TIL) from tumors, tumor tissues were cut into small pieces and placed into $40 \mu \mathrm{m}$ Nylon Cell Strainers in $10 \mathrm{ml}$ cold PBS, and single-cell suspension was prepared by using hub of syringe.
After centrifugation, the resulting cell suspension was washed once in HBSS, resuspended in $5 \mathrm{ml}$ Histopaque-1077 (Sigma), and placed in a sterile $15 \mathrm{ml}$ conical tube, which was centrifuged for $30 \mathrm{~min}$ at 3300 r.p.m. at room temperature. The gray layer was collected. After washing with DMEM once, the cells were incubated with $1 \mathrm{ml}$ red blood cell lysis buffer (Sigma) for $5 \mathrm{~min}$ at room temperature; subsequently, $25 \mathrm{ml}$ sterile PBS was added to stop the lysis. The cells were washed, counted, and stained with antibodies to CD3, CD4, CD8, and CD25 for flow cytometry analysis.

\section{Statistical Analysis}

The statistical significance between values was determined by Student's $t$-test. All data were expressed as the mean \pm s.d. Probability values of $P \leq 0.05$ were considered significant.

\section{RESULTS \\ Murine Tumor Cell Line Grows and Initiates Immune Response in Immunocompetent BALB/c Mice}

The murine cell line 1MEA was a chemically transformed cell line from a $\mathrm{BALB} / \mathrm{c}$ mouse. To demonstrate the tumorigenic potential, we injected 5 million 1MEA cells per mouse s.c. into the right-hind flank of the mouse. Tumors could be palpated around 10 days in all the mice injected (total number 25). As demonstrated in Figure 1, the average tumor size was around $1.8 \mathrm{~cm}$, in greatest dimension, in about 2 weeks (Figures 1a and b). Histologically, the tumor showed features of poorly differentiated HCC (Figure 1c). Marked
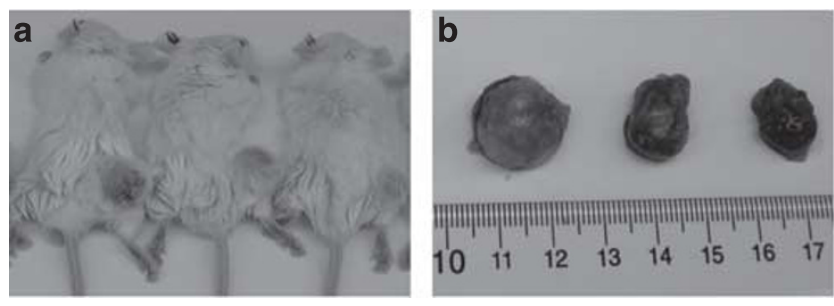

e

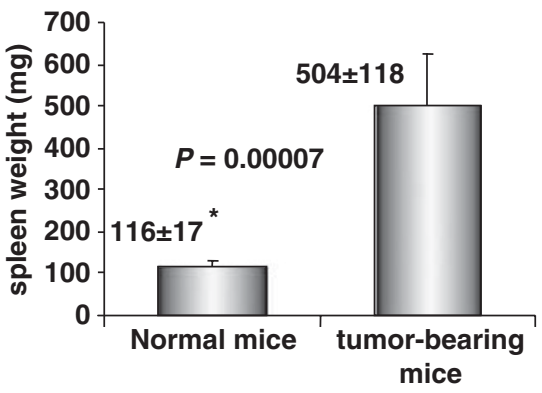

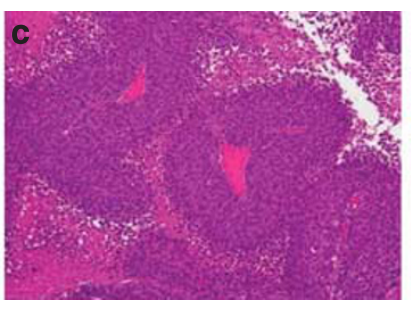

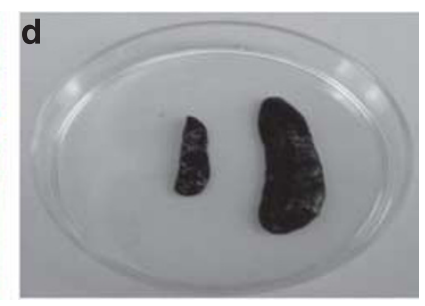

f

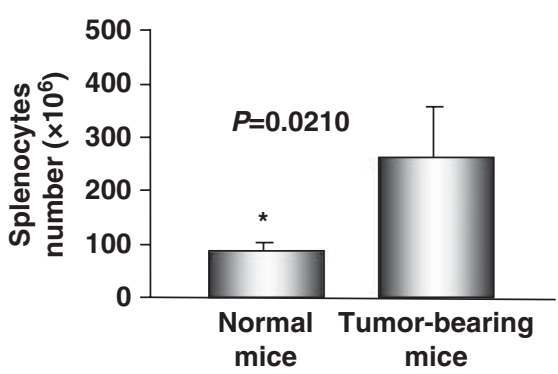

Figure 1 Tumor growth and enlarged spleens in immunocompetent BALB/c mice. BALB/c mice (6- to 8-week old) were injected (s.c.) 1MEA cells $\left(5 \times 10^{6} /\right.$ per mouse). After 2 weeks, the tumors were measurable. As mentioned in Materials and Methods, at the end point of experiments (the end of the fourth week), spleens and tumor tissues were collected and weighed. Splenocytes were prepared and counted after red cells lysis. (a) Tumor-bearing BALB/c mice; (b) Tumor tissue separated from the mice. (c) Histological features of the liver cancer tissue (H\&E stain) showing poorly differentiated hepatocellular carcinoma; (d) the size of spleens from BALB/c mice with tumor (right) and normal mice (left); (e) the weight of spleens from normal mice and tumor-bearing mice $(n=9)$; $(\mathbf{f})$ the splenocytes from normal mice $\left(87 \pm 14 \times 10^{6} ; n=3\right)$ and tumor-bearing mice $\left(263 \pm 95 \times 10^{6} ; n=5\right)$. Data represent the mean \pm s.d. from one of two similar experiments. 
splenomegaly occurred in virtually all the mice that had tumor growth (Figure 1d). On average, the size of the spleen in a tumor-bearing mouse was three times larger than that of the control mouse (Figures $1 \mathrm{e}$ and $\mathrm{f}$ ). The size of the spleens was consistent with the number of splenic cells when total splenic cells were counted. Both CD4 and CD8 cells were present in the spleen, and the ratio of CD4/CD8 was not significantly altered. Histologically, there was no significant morphological difference between spleens from the control mice and from the tumor-bearing mice (data not shown).

a

spleen
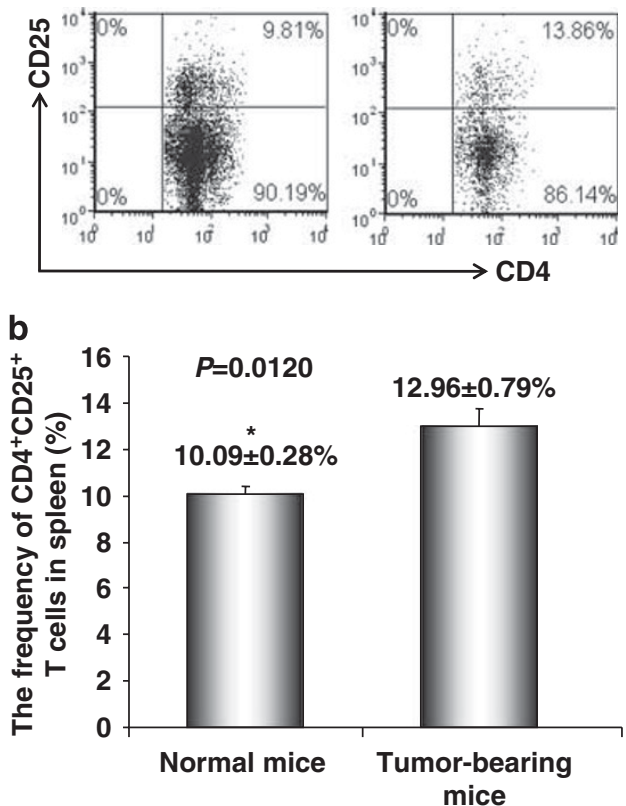

\section{Liver Cancer Upregulates Immunosuppressive Cell Population in Mice}

As we have previously reported, HCC patients have higher percentage of Tregs $\left(\mathrm{CD} 4{ }^{+} \mathrm{CD} 25^{+}\right) .{ }^{25}$ To investigate whether the similar phenomenon is also present in the mouse model, we firstly examined the $\mathrm{CD} 4{ }^{+} \mathrm{CD} 25^{+}$Tregs in tumor-bearing mice. $\mathrm{CD}^{+} \mathrm{T}$ cells were gated for the presence of $\mathrm{CD}^{+}$and $\mathrm{CD} 25^{+} \mathrm{T}$ cells. As shown in Figures 2a and b, tumor-bearing mice had higher numbers of $\mathrm{CD} 4{ }^{+} \mathrm{CD} 25^{+}$ cells, which is consistent with findings in HCC patients. The data suggests that HCC induces immunosuppressive

C

spleen
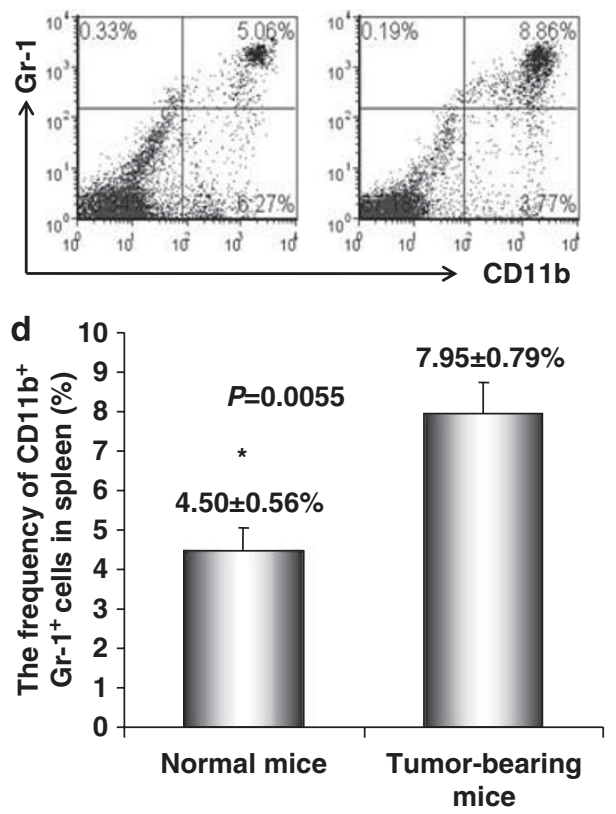

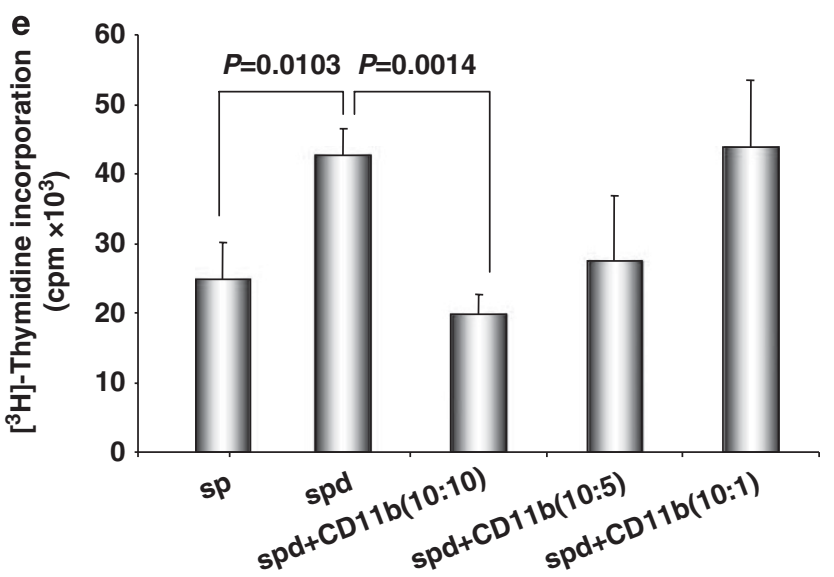

Figure 2 Increased $\mathrm{CD}^{+}{ }^{+} \mathrm{CD} 25^{+} \mathrm{T}$ cells and $\mathrm{CD} 11 \mathrm{~b}^{+} \mathrm{Gr}-1^{+}$cells in tumor-bearing mice. (a) A representative flow cytometric data showing the $\mathrm{CD} 4{ }^{+} \mathrm{CD} 25^{+} \mathrm{T}$-cell frequency of gated CD4 ${ }^{+} \mathrm{T}$ cells in splenocytes from normal and HCC tumor-bearing mice; (b) Mean $\mathrm{CD} 4{ }^{+} \mathrm{CD} 25^{+} \mathrm{T}$-cells frequency in $\mathrm{CD}^{+}{ }^{+} \mathrm{T}$ cells in splenocytes from normal and HCC tumor-bearing mice $(n=3)$. $(\mathbf{c}, \mathbf{d})$ Representative $(\mathbf{c})$ and mean $(\mathbf{d})$ flow cytometry data showing increased $\mathrm{CD} 11 \mathrm{~b}^{+} \mathrm{Gr}-1^{+}$cells frequency in splenocytes from normal and HCC tumor-bearing mice $(n=3)$. The gated viable cells were analyzed. Numbers in the figures represent the percentage of fluorescence-positive cells in corresponding areas; (e) Functional analysis of CD11 $\mathrm{b}^{+}$cells were evaluated for their ability to suppress autologous $\mathrm{CD} 11 \mathrm{~b}^{+}$-depleted splenocytes proliferation by $\left[{ }^{3} \mathrm{H}\right]$-thymidine incorporation when stimulated with anti-CD3 and $\mathrm{CD} 28$ at various ratios. Values represent mean \pm s.d. $(n=3)$ and are representative examples of three separate experiments. 
population in this mouse model that is similar to that observed in human disease.

Another population of suppressive cells, MDSC, has been recently defined as $\mathrm{CD} 11 \mathrm{~b}^{+} \mathrm{Gr}-1^{+}$. This cell population has been reported to increase in a number of cancers, including head-neck, pancreatic, HCC, renal, and breast cancers. ${ }^{26,34,35}$ We next examined this population of cells in this animal model. Population of $\mathrm{CD} 11 \mathrm{~b}^{+} \mathrm{Gr}-1^{+}$MDSC was significantly expanded in tumor-bearing mice (Figures $2 \mathrm{c}$ and $\mathrm{d}$ ). To confirm the immunosuppressive activity of these MDSC, we performed cell proliferation assay. As shown in Figure 2e, MDSC inhibited T-cell proliferation.

\section{Sorafenib Inhibits HCC Growth in the Mouse Model}

Sorafenib has been approved as a systemic therapeutic agent for advanced HCC. Clinical trials indicate that treatment with Sorafenib modestly increases patient survival. ${ }^{36,37}$ To validate the animal model, we tested the effect of Sorafenib on tumor growth. Mice were first injected with 1MEA cells s.c. At 2 weeks after the injection, when the tumor average size is around $0.4 \mathrm{~cm}$, Sorafenib treatment was initiated with daily dose of $30 \mathrm{mg} / \mathrm{kg}$. After 2 weeks of treatment, the mice were sacrificed and tumor sizes were measured. As shown in Figure 3, Sorafenib significantly inhibited tumor growth; the average tumor size was three times smaller than the control group.

\section{Sorafenib Downregulates Immunosuppressive Cell Population}

To further evaluate the mechanisms of Sorafenib inhibition of HCC, we tested the hypothesis whether Sorafenib would exert anti-tumor activity through modulating suppressive populations of the immune cells. ${ }^{38,39}$ We first determined the effect of Sorafenib on $\mathrm{CD} 4{ }^{+}, \mathrm{CD} 8^{+}, \mathrm{CD} 4{ }^{+} \mathrm{CD} 25^{+}$, and $\mathrm{CD} 11 \mathrm{~b}^{+} \mathrm{Gr}-1^{+}$cells in the spleens and bone marrows of normal mice by flow cytometric analysis. As shown in Figures $4 a$ and $b$, Sorafenib had no significant effects on these cells in normal mice. Then we analyzed the effects of Sorafenib on $\mathrm{CD} 4{ }^{+} \mathrm{CD} 25^{+} \mathrm{FOXP}_{3}{ }^{+}$Tregs and $\mathrm{CD} 11 \mathrm{~b}^{+} \mathrm{Gr}-1^{+}$MDSC in tumor environments. As shown in Figures $4 \mathrm{c}$ and d, tumorbearing mice had significantly elevated Tregs, whereas the treatment of Sorafenib restored the Tregs population and Foxp3 expression in $\mathrm{CD} 4{ }^{+} \mathrm{CD} 25^{+} \mathrm{T}$ cells to the normal level. Sorafenib treatment also significantly reduced the number of $\mathrm{CD} 11 \mathrm{~b}^{+} \mathrm{Gr}-1^{+}$cells in both bone marrows and the spleens. The number of $\mathrm{CD} 11 \mathrm{~b}^{+} \mathrm{Gr}-1^{+}$cells was even lower than the normal mice control, suggesting that Sorafenib prevented $\mathrm{CD} 11 \mathrm{~b}^{+} \mathrm{Gr}-1^{+}$cell differentiation. To evaluate overall inhibitory effect of Sorafenib on the cellular immune system, we analyzed the absolute cell numbers of $\mathrm{CD} 4{ }^{+}, \mathrm{CD}^{+}, \mathrm{CD}^{+}{ }^{+} \mathrm{CD} 25^{+}$, and $\mathrm{CD} 11 \mathrm{~b}^{+} \mathrm{Gr}-1^{+}$cells in these mice. The data in Table 1 show that splenomegaly in tumor-bearing mice is associated with significantly increased absolute cell number of $\mathrm{CD} 4{ }^{+} \mathrm{CD} 25^{+}$Tregs and $\mathrm{CD} 11 \mathrm{~b}^{+}$ Gr- $1^{+}$cells. Sorafenib did not alter the overall $\mathrm{CD}^{+}$and
$\mathrm{CD}^{+}$cells numbers and their ratio (Table 1, Figure 5). By inference, Sorafenib exhibited relative specific activity on Tregs and MDSC.

Lastly, we evaluated for the presence of tumor-infiltrating lymphocytes by using immunohistochemical staining and flow cytometry. Unexpectedly, no significant numbers of $\mathrm{CD} 3, \mathrm{CD} 4$, or $\mathrm{CD} 8 \mathrm{~T}$ cells were detected in the tumor tissues (data not shown).

\section{DISCUSSION}

There are a number of animal models being used for the study of liver cancer. However, most of the models rely on transgenic and knockout mice. The major disadvantage of these mouse models is the limitation of studying immune regulation because of the immune tolerance developed in these mice. Recently, an immunocompentent mouse model has been described for the study of dendritic cells. ${ }^{32}$ There is emerging evidence that immune responses have a significant role in the development and progression of HCC. Thus, a robust mouse model that possesses intact immunity would be a valuable system for the study of HCC.

A murine HCC cell line, 1MEA, was first established two decades ago through chemical carcinogenesis of the immortalized cell line, BNL-derived from a BALB/C mouse. ${ }^{33}$ The 1MEA cells can readily grow into tumor in BALB/c mice, indicating that there is no immune rejection to this tumor in these mice. This observation prompted us to ask the following questions: (1) Can the 1MEA tumor cells initiate immune response in the mice? (2) What is the nature of these immune responses that allow the tumor growth in an immunocompetent mouse?, and (3) Can the immune responses be modulated and tumor growth altered? Through a series of experiments, we have begun to answer these questions.

Murine HCC cell line initiates robust immune response in $\mathrm{BALB} / \mathrm{c}$ tumor. Our experiments clearly demonstrated that 1 MEA cell line could grow in $B A L B / c$ mice with a high rate of efficiency. With 5 million cells in the initial injection, a $1-\mathrm{cm}$ tumor is visible within 2 weeks. Although we focused on tumor ectopic growth for the purpose of conveniently monitoring tumor size, we have also implanted tumor cells in the mouse livers and achieved similar tumor growth. The tumors are locally invasive to the surrounding tissue but metastasis is not observed, even in mice with primary tumor size as large as $4.5 \mathrm{~cm}$.

One notable gross finding of the tumor-bearing mice is the enlargement of spleens, which has been noticed in several other cancer murine models. ${ }^{40,41}$ The enlarged spleens suggest the initiation of immune responses to the tumors. The size of the spleens positively correlated with the tumor burdens, as shown in Figure 1. Extensive evaluation of splenocytes suggests that the splenic enlargement is associated with increased numbers of immune cells, mainly Tregs and MDSC cells. The overall number of CD4 and CD8 cells, and their ratios are not significantly altered. Histologically, there was no distinctive morphological difference between the spleens 
a

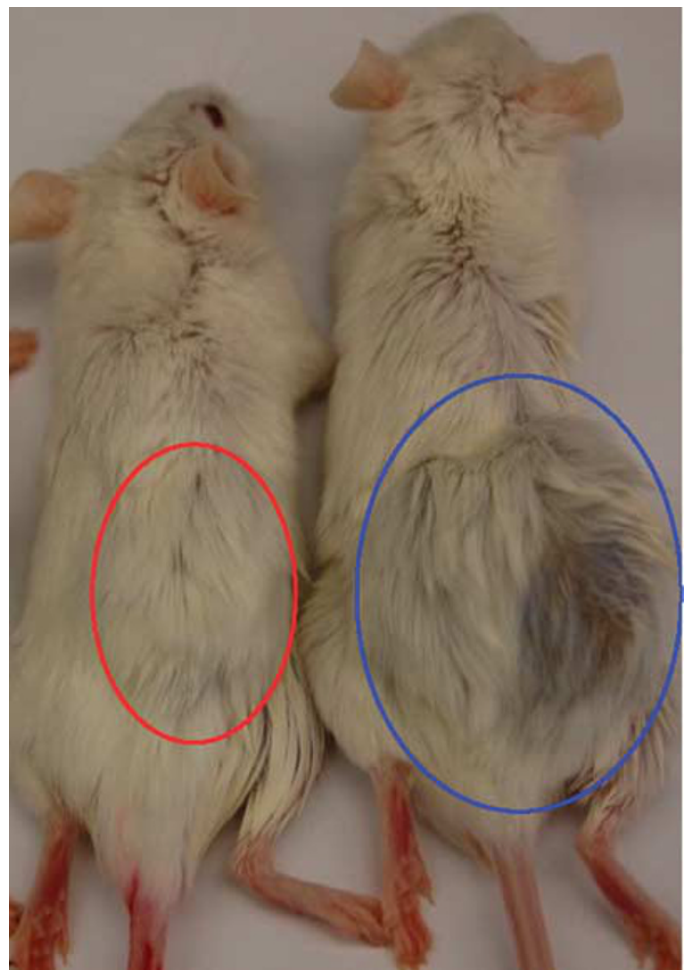

b

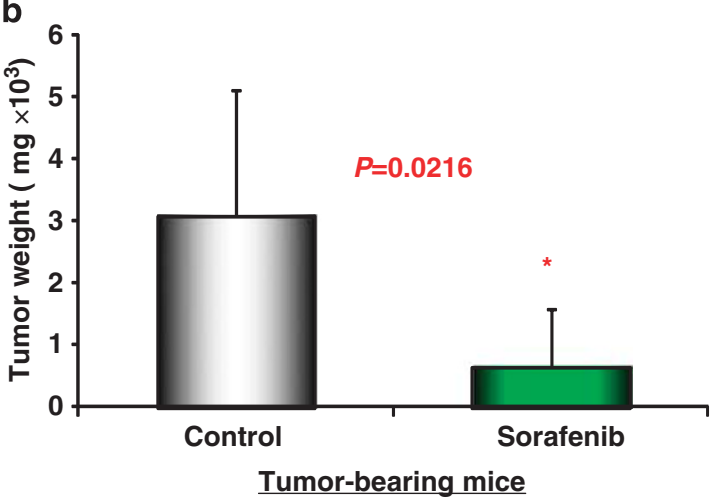

Sorafenib

Control
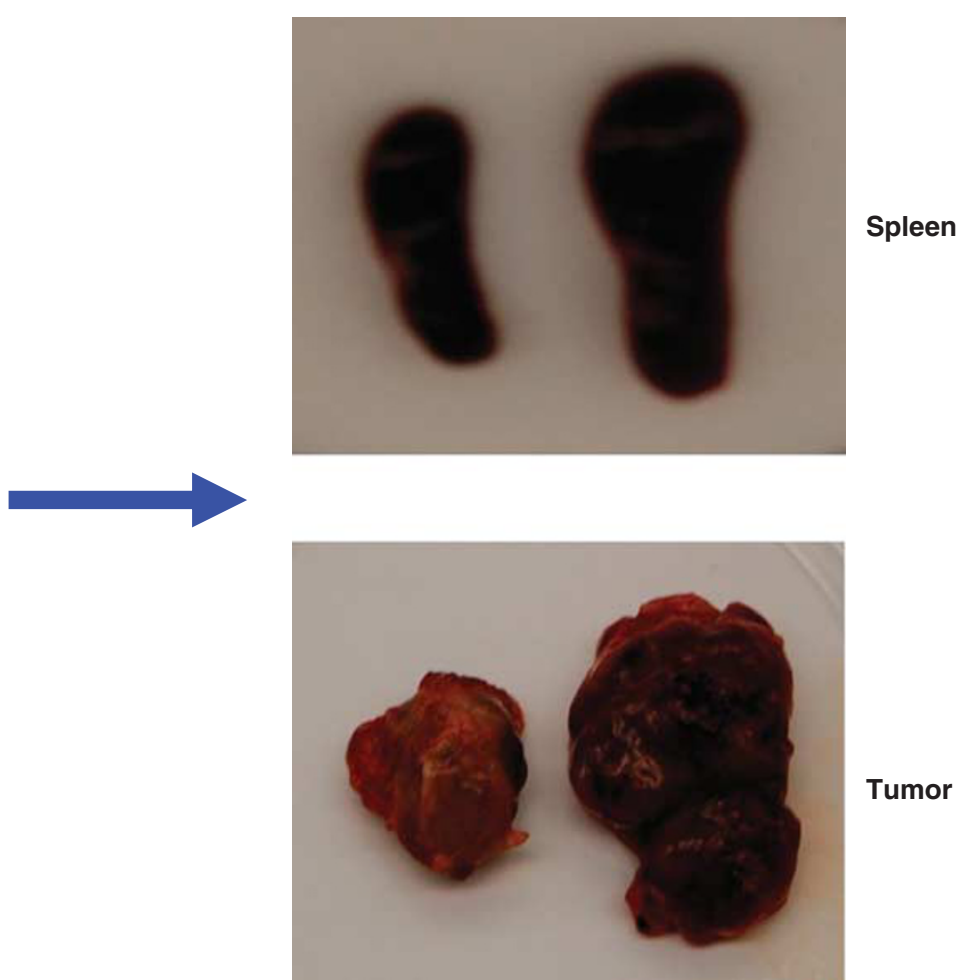

Tumor

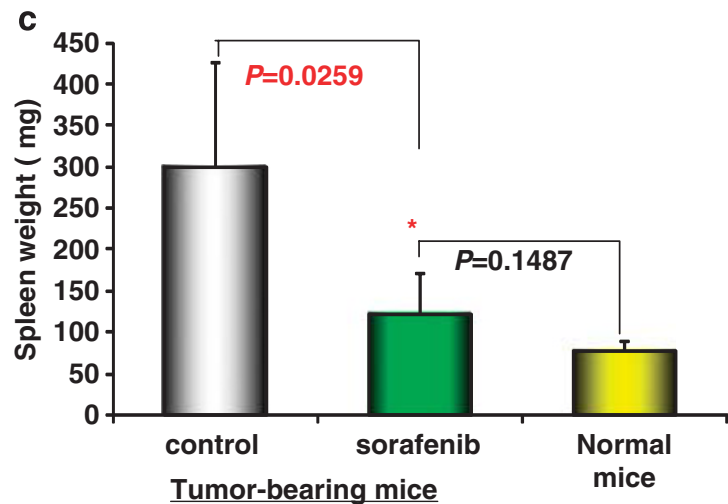

Figure 3 Sorafnib inhibits HCC growth in BALB/c mice. BALB/c mice (6-8 weeks old) were s.c. injected with $1 \mathrm{MEA}$ cells ( 4 million/mouse) in the right flank. At 2 weeks later, the mice with measurable tumor were divided into two groups. Each mouse was gavage-fed with Sorafenib $(0.6 \mathrm{mg} / 100 \mu \mathrm{l})$ or solvent $(100 \mu \mathrm{l})$, once daily, 5 days each week, for 2 weeks. At end point of experiments, mice were sacrificed; tumors and spleens were collected, and weighed. (a) Representative of HCC tumor-bearing mice after 2 weeks treatment with Soarfenib (left) or solvent (right), spleen (right upper), and tumor (right lower) size. (b) The weight of tumor tissues from tumor-bearing mice after 2 weeks treatment with Sorafenib or solvent $(n=5)$. (c) The weight of spleens from normal mice or tumor-bearing mice after 2 weeks treatment with Sorafenib or solvent $(n=5)$. Data represent the mean \pm s.d. of five mice per group from one representative experiment of two similar experiments. ${ }^{\star} P \leq 0.05$.

taken from normal and tumor-bearing mice. The observation of the splenomegaly in the mice is interesting considering that such phenomenon does not exist in human liver cancer patients.

As our experiments demonstrated, HCC could readily grow in the mice in spite of the robust immune responses. This observation would suggest that specific anti-tumor activity must have been inhibited. We have reported before that human HCC induces an immunosuppressive phenotype, as reflected by the increased circulating Tregs. ${ }^{25}$ Recently, another suppressive population of cells MDSC have been shown to be elevated in HCC patients. ${ }^{26}$ Therefore, we decided to examine Tregs and MDSC present in the tumorbearing mice. Our data show that both Tregs and MDSC were significantly upregulated in these mice, and they were positively correlated with tumor burden. Moreover, the MDSC cells also exhibited typical suppressive activity when cocultured with effector $\mathrm{T}$ cells. We have previously reported 

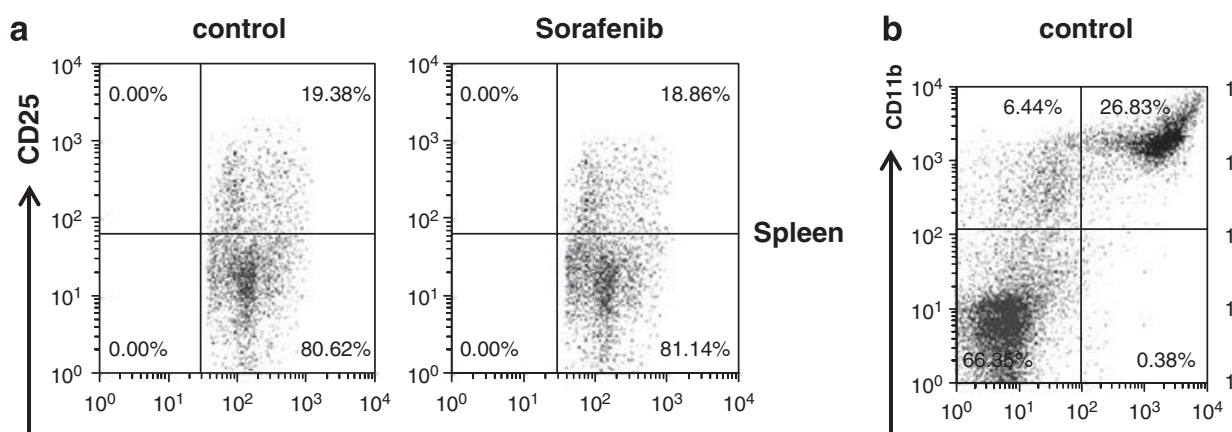

Sorafenib
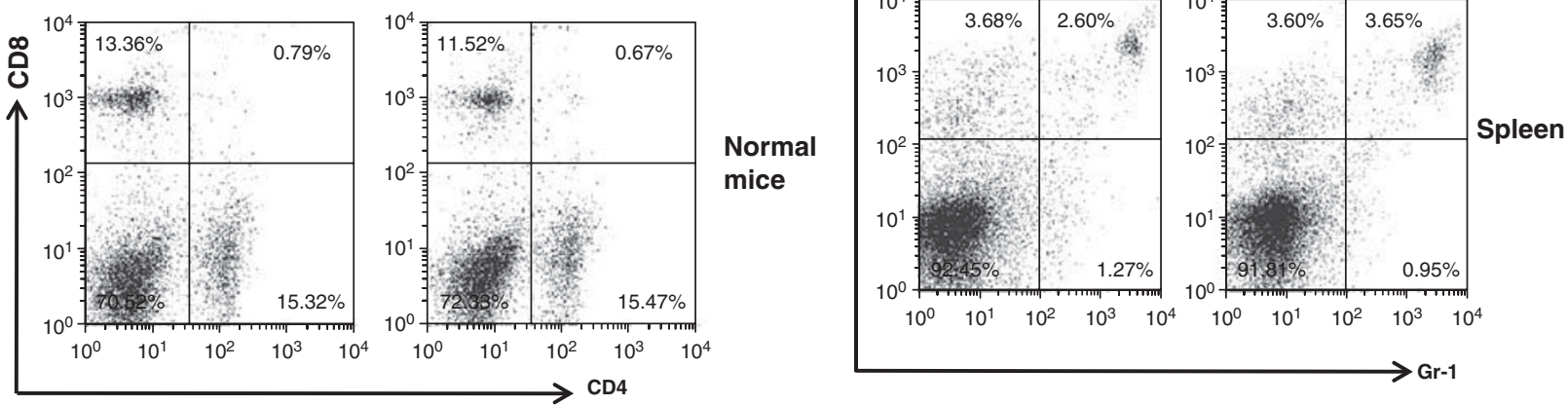

C

Normal mice

Tumor-bearing mice
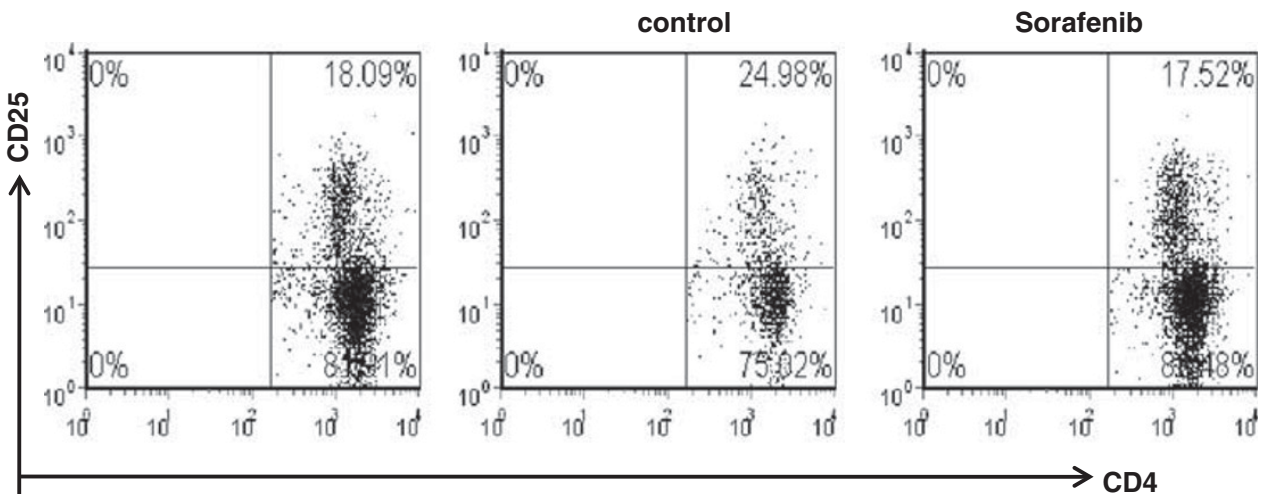

Spleen
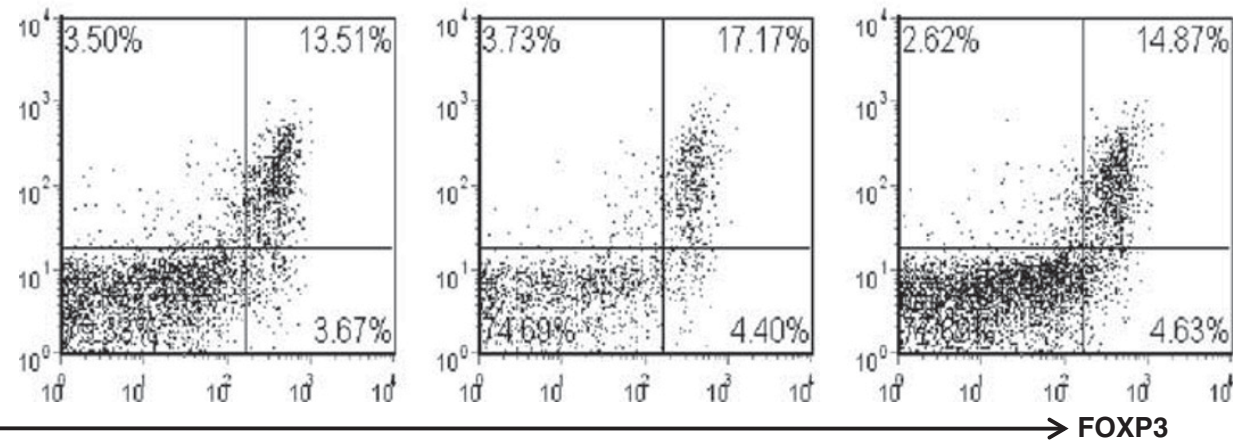

Figure 4 Sorafenib treatment significantly decreased the percentage of $\mathrm{CD} 4{ }^{+} \mathrm{CD} 25^{+} \mathrm{T}$ cells and $\mathrm{CD} 11 \mathrm{~b}^{+}$cells in tumor-bearing mice. (a, b) Representative of flow cytometry data showing the frequency of $\mathrm{CD} 4{ }^{+} \mathrm{CD} 25^{+} \mathrm{T}$ cells and $\mathrm{CD} 11 \mathrm{~b}^{+} \mathrm{Gr}-1^{+}$cells in spleens and bone marrow from normal mice or tumorbearing mice treated with solvent or Sorafenib; (c, d) Representative (c) and collective (d, $n=3)$ of flow cytometry data showing the expression of FOXP3 in $\mathrm{CD}^{+}{ }^{+} \mathrm{CD} 25^{+} \mathrm{T}$ cells in spleens from normal mice or tumor-bearing mice treated with solvent or Sorafenib; (e) A representative of flow cytomrtey data showing the frequency of $\mathrm{CD} 11 \mathrm{~b}^{+} \mathrm{Gr}-1^{+}$cells in bone marrow (upper panel) and spleen (lower panel) from normal mice or tumor-bearing mice treated with solvent or Sorafenib; (f) Mean $\mathrm{CD} 11 \mathrm{~b}^{+} \mathrm{Gr}-1^{+}$cells frequency bone marrow and spleen from normal and HCC tumor-bearing mice treated with solvent or Sorafenib $(n=5)$. Data represent the mean \pm s.d. of three or five mice per group from one representative experiment of two similar experiments. 


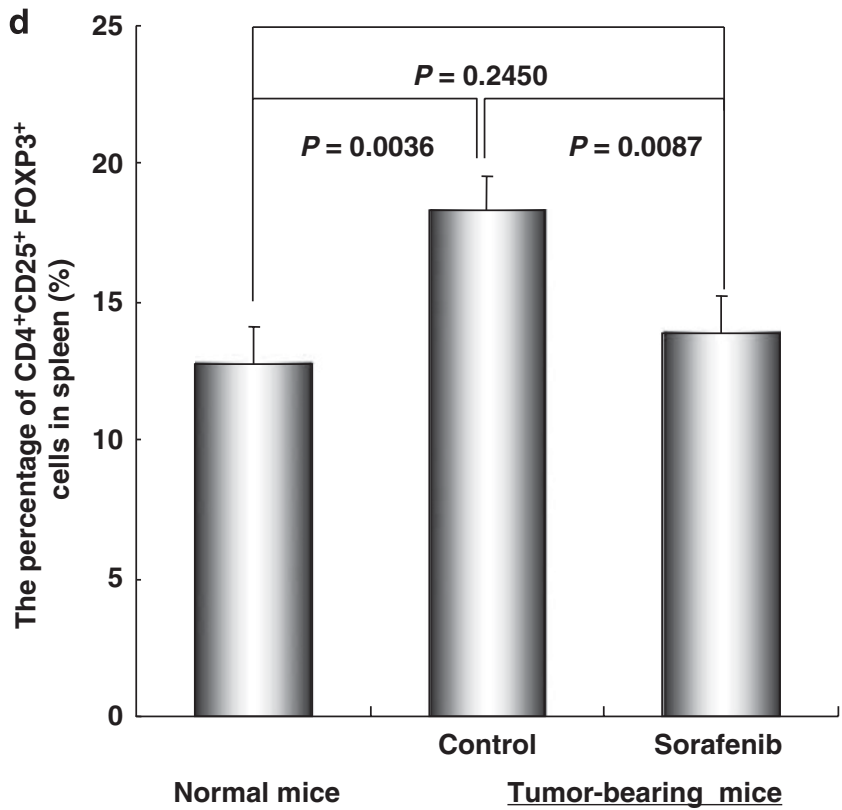

e

Normal mice

Tumor-bearing mice
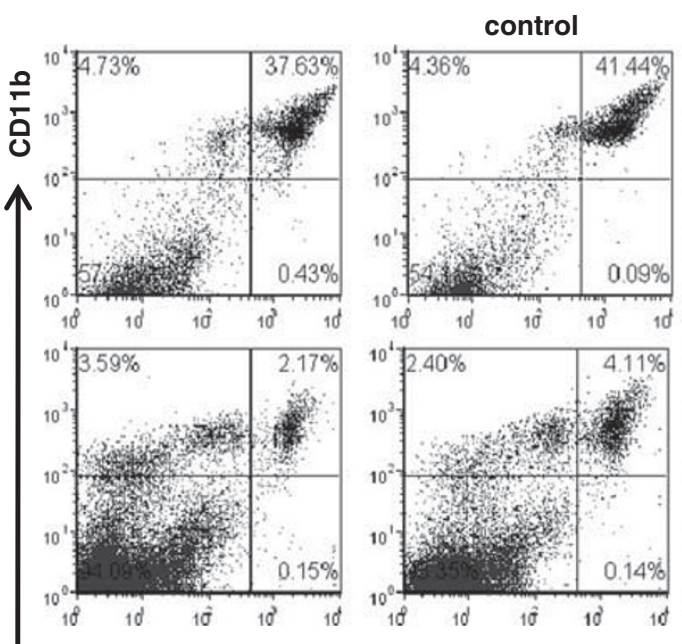

Sorafenib
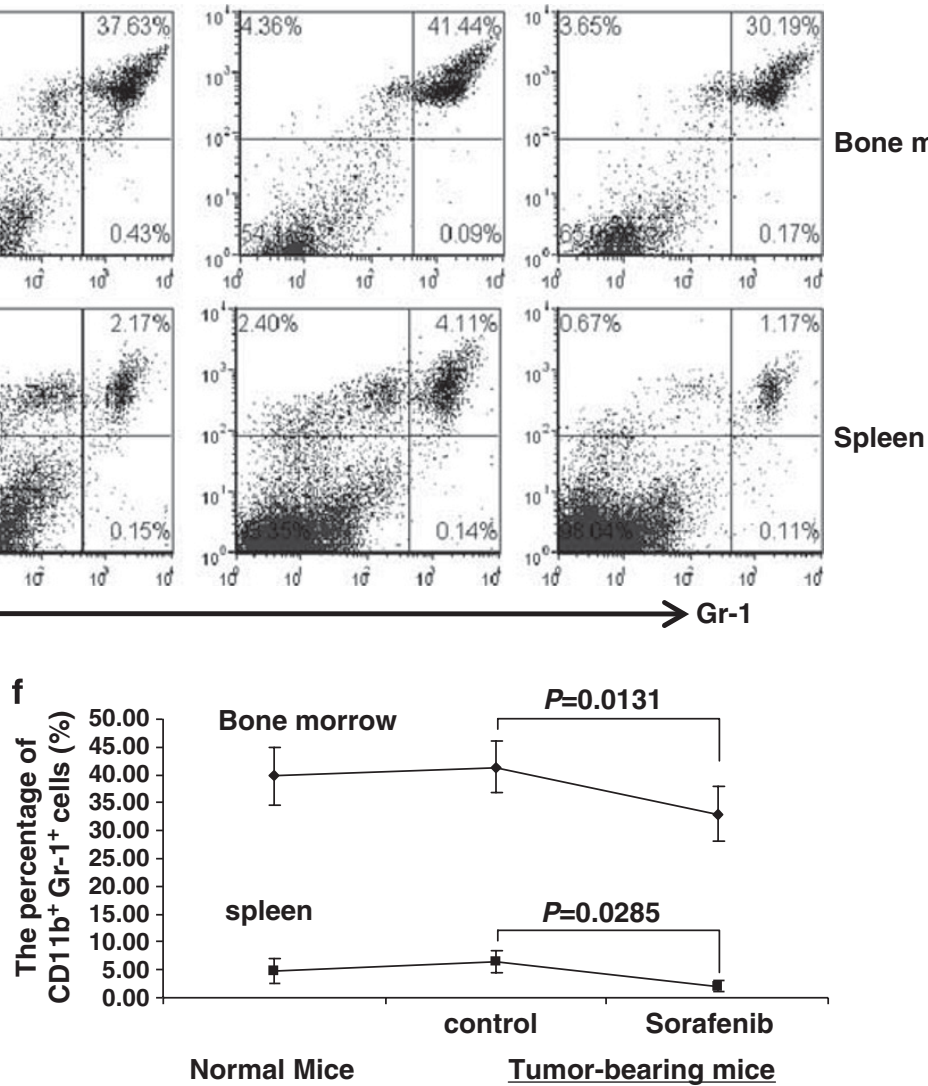

Figure 4 Continued.

that supernatants from human HCC cell lines can promote Tregs in vitro, indicating that tumor cells can secrete factors that modulate host immune system by promoting immunosuppressive populations. ${ }^{23}$ Identification of these factors would have a significant impact on the understanding of the tumor immunity and immune modulation for anti-tumor activity. One potential limitation of our current model is the fact that we have injected tumor in an ectopic 
site rather than in the natural location of the liver. Further experiments will validate these finding using an orthotopic model.

The precise mechanism by which Sorefanib influences HCC progression and patient survival is unclear. As it is a kinase inhibitor, one possible mechanism is that it directly induces cancer cell apoptosis or inhibits cancer cell proliferation. Such activity has been reported previously. ${ }^{42}$ We tested the in vitro activity of Sorafenib in 1MEA cells and

\section{Table 1 Splenomegaly and increased absolute numbers of $\mathrm{CD4}^{+} \mathrm{CD}^{2} 5^{+}$regulatory $\mathrm{T}$ cells and $\mathrm{CD} 11 \mathrm{~b}^{+} \mathrm{Gr}-1^{+}$cells in tumor-bearing mice}

\begin{tabular}{lccc}
$\begin{array}{l}\text { Cell number } \\
\left(\times 10^{6}\right)\end{array}$ & $\begin{array}{c}\text { Normal } \\
\text { mice }\end{array}$ & $\begin{array}{c}\text { Tumor-bearing } \\
\text { mice } \\
\text { (control group) }\end{array}$ & $\begin{array}{c}\text { Tumor-bearing } \\
\text { mice } \\
\text { (Sorafenib group) }\end{array}$ \\
\hline $\mathrm{CD} 4$ & $32.8 \pm 4.3$ & $32.3 \pm 7.4$ & $36.8 \pm 6.2$ \\
$\mathrm{CD} 8$ & $20.9 \pm 2.8$ & $23.7 \pm 5.4$ & $21.8 \pm 3.7$ \\
$\mathrm{CD} 4^{+} \mathrm{CD} 25^{+}$ & $3.6 \pm 0.5^{\mathrm{a}}$ & $5.3 \pm 1.2$ & $2.8 \pm 0.5^{\mathrm{a}}$ \\
$\mathrm{CD}^{\mathrm{a}} 1 \mathrm{~b}^{+} \mathrm{Gr}-1^{+}$ & $7.2 \pm 0.9^{\mathrm{a}}$ & $19.2 \pm 4.4$ & $5.6 \pm 0.9^{\mathrm{a}}$ \\
\hline
\end{tabular}

${ }^{\mathrm{a}}$ Normal vs control group $P<0.05$.

Spleens from normal or tumor-bearing mice treated with or without Sorafenib were prepared into single-cell suspension. After red cell lysing and wash, cells were suspended, counted, and stained with antibodies for CD3, CD4, CD8, $\mathrm{CD} 25, \mathrm{CD} 11 \mathrm{~b}$, and $\mathrm{Gr}-1$, then analyzed by flow cytometry. The absolute numbers of cells were figured out based on the total number of splenocytes and percentages of $\mathrm{CD}^{+}, \mathrm{CD}^{+}, \mathrm{CD}^{+} \mathrm{CD} 25^{+}$and, $\mathrm{CD} 11 \mathrm{~b}^{+} \mathrm{Gr}-1^{+}$cells in spleens. Values represent mean \pm s.d. from four mice per group from one of two independent similar experiments. no significant tumor cell death was seen, but there was a significant impact on 1MEA cell proliferation (data not shown). We then tested the effect of Sorafenib in the mouse model. As our data shown in Figure 3, Sorafenib exhibited overt anti-tumor activity, which is unlikely because of antiproliferation alone. We then examined the possibility of the immunomodulatory effect of Sorafenib in the HCC model. Indeed, the animals treated with the drug exhibited significantly reduced numbers of both Tregs and MSDC. This data suggests an immunomodulatory mechanism of Sorafenib on HCC in vivo. The marked decrease in MDSC from the bone marrow also suggests a direct effect on progenitor cell production, which requires further investigation. One note of caution is that we cannot exclude the possibility of the secondary effect on the suppressive populations, ie, the slow growth of HCC caused by Sorafenib would have less capacity to induce Tregs and MDSC. We believe that both direct and indirect effects may exist in the Sorafenib-treated mice.

There are recent reports about the effect of sunitinib, another kinase inhibitor, on the inhibition of MDSC. ${ }^{31}$ OzaoChoy et $a^{38}$ hypothesized that malate, a receptor tyrosine kinase inhibitor, could reverse MDSC-mediated immune suppression and modulate the tumor microenvironment, thereby improving the efficacy of immune-based therapies. Treatment with sunitinib decreased the number of MDSC and Treg in advanced tumor-bearing animals. Furthermore, it not only reduced the suppressive function of MDSC but also prevented tumor-specific T-cell anergy and Treg development. Interestingly, sunitinib treatment resulted in

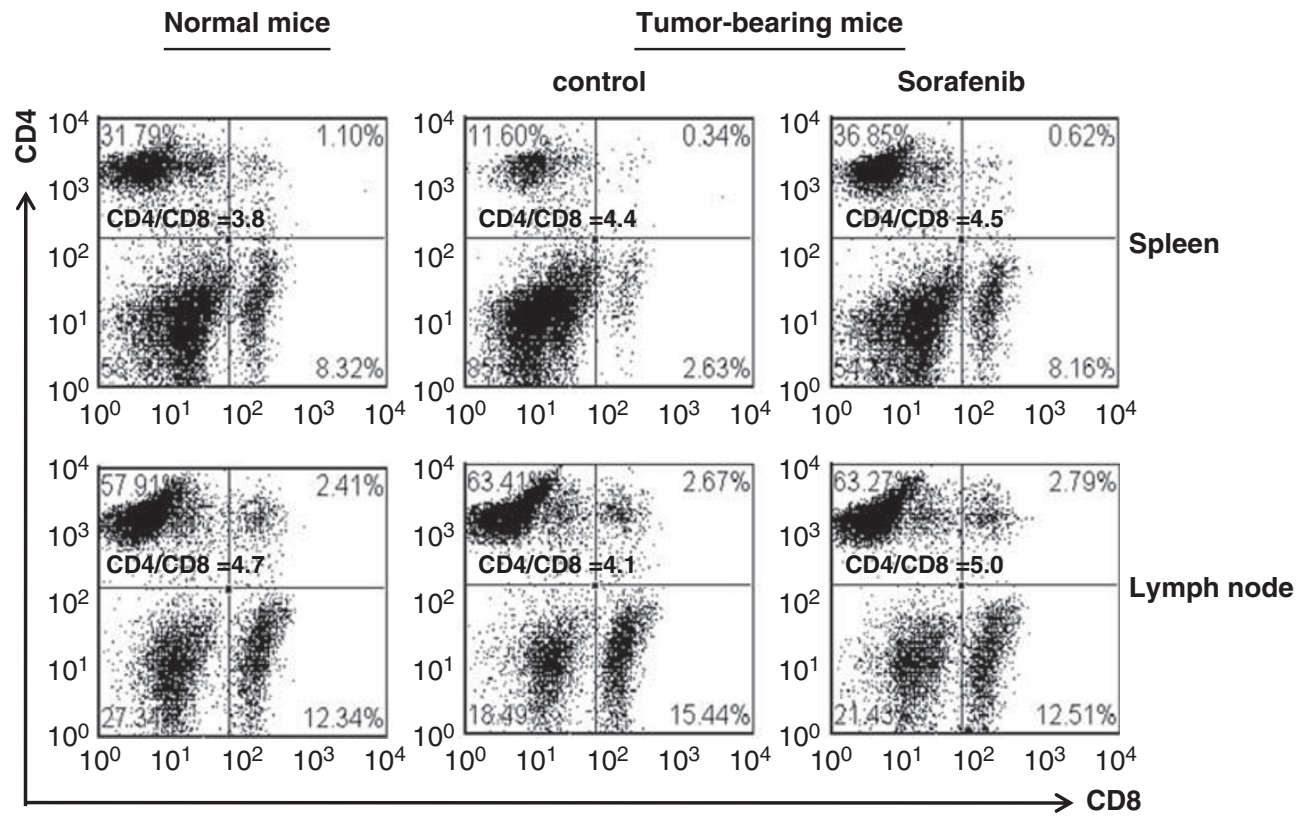

Figure 5 Sorafenib treatment maintained the CD4 and CD8 cells in spleen and lymph nodes. A representative flow cytometric data showing the CD4 ${ }^{+}$and $\mathrm{CD}^{+}{ }^{+}$-cells frequency of gated lymphocytes in spleen and lymph nodes from normal and HCC tumor-bearing mice treated with solvent or soarfenib. Numbers in the figures represent the percentage of fluorescence-positive cells in corresponding areas, representative data of three independent experiments. 
reduced expression of interleukin (IL)-10, transforming growth factor-beta, and Foxp3, but enhanced expression of Th1 cytokine IFN-gamma and increased CTL responses in isolated tumor-infiltrating leukocytes.

In a variety of human solid tumors, TIL are considered to have an important role in anticancer immune surveillance. Among the mature human T-cell population, three subtypes appear to have a major role in immunosurveillance against tumor growth: $\mathrm{CD}^{+}, \mathrm{CD} 4^{+}$, and Treg cells. Curiel et al ${ }^{43}$ reported that tumor infiltration by Treg cells predicted reduced survival, but others have failed to reproduce this finding. ${ }^{44}$ In many rodent tumor models, the mobilization of T-cell responses is also sufficient to eradicate tumors early during their establishment. ${ }^{45,46}$ However, such mobilization is clearly less effective when it occurs late during tumor progression, in both rodent tumor models and in human cancer patients. ${ }^{47,48}$ Studies suggested an inability of functionally normal $\mathrm{T}$ cells to infiltrate or persist in late-stage solid tumors because of physical barriers and/or emigration from the tumor site. ${ }^{48,49}$ In our study, we did not detect significant infiltration of $\mathrm{T}$ cells in the tumor tissues. The reason may be partially because of late stage of tumor progression or the ectopic nature of the tumor.

In summary, we have established a novel, immunocompetent HCC mouse model that demonstrates the relevance to human HCC. Using this model, we have studied the immune response to HCC and examined the treatment effect of kinase inhibitor, Sorafenib. Our results show that HCC can upregulate immunosuppressive population of cells: Tregs and MDSC. We also found that Sorefanib modulated immune responses by suppressing Tregs and MDSC. We believe that this validated model can be used for understanding the immunoregulations in HCC, immunotherapy, and evaluating novel therapeutic agents.

\section{ACKNOWLEDGEMENT}

The work was supported in part by CA133086 and RR023976 from NIH to Chen Liu, and Al061158 and UL1RR029890 to David Nelson.

\section{DISCLOSURE/CONFLICT OF INTEREST}

The authors declare no conflict of interest.

1. Bosch FX, Ribes J, Diaz $M$, et al. Primary liver cancer: worldwide incidence and trends. Gastroenterology 2004;127:S5-S16.

2. El-Serag HB. Hepatocellular carcinoma: recent trends in the United States. Gastroenterology 2004;127:S27-S34.

3. Matar $\mathrm{P}$, Alaniz $\mathrm{L}$, Rozados $\mathrm{V}$, et al. Immunotherapy for liver tumors: present status and future prospects. J Biomed Sci 2009;16:30.

4. Unitt E, Marshall A, Gelson W, et al. Tumour lymphocytic infiltrate and recurrence of hepatocellular carcinoma following liver transplantation. J Hepatol 2006;45:246-253.

5. Cabrera R, Ararat $M$, Cao $M$, et al. Hepatocellular carcinoma immunopathogenesis: clinical evidence for global $T$ cell defects and an immunomodulatory role for soluble CD25 (sCD25). Dig Dis Sci 2010; 55:484-495.

6. Chen $Y$, Zhou $Y$, Qiu S, et al. Autoantibodies to tumor-associated antigens combined with abnormal alpha-fetoprotein enhance immunodiagnosis of hepatocellular carcinoma. Cancer Lett 2010 289:32-39.
7. Stift A, Friedl J, Dubsky P, et al. Dendritic cell-based vaccination in solid cancer. J Clin Oncol 2003;21:135-142.

8. Llovet JM. Updated treatment approach to hepatocellular carcinoma. J Gastroenterol 2005;40:225-235.

9. Wang XG, Revskaya E, Bryan RA, et al. Treating cancer as an infectious disease-viral antigens as novel targets for treatment and potential prevention of tumors of viral etiology. PLoS One 2007;2:e1114.

10. Shibolet $O$, Alper $R$, Zlotogarov $L$, et al. Suppression of hepatocellular carcinoma growth via oral immune regulation towards tumorassociated antigens is associated with increased NKT and CD8+ lymphocytes. Oncology 2004;66:323-330.

11. Greten TF, Manns MP, Korangy F. Immunotherapy of HCC. Rev Recent Clin Trials 2008:3:31-39.

12. Butterfield LH. Immunotherapeutic strategies for hepatocellular carcinoma. Gastroenterology 2004;127:S232-S241.

13. Sung YK, Hwang SY, Park MK, et al. Glypican-3 is overexpressed in human hepatocellular carcinoma. Cancer Sci 2003;94:259-262.

14. Yuen MF, Lai CL. Serological markers of liver cancer. Best Pract Res Clin Gastroenterol 2005;19:91-99.

15. Gonzalez-Carmona MA, Marten A, Hoffmann P, et al. Patient-derived dendritic cells transduced with an a-fetoprotein-encoding adenovirus and co-cultured with autologous cytokine-induced lymphocytes induce a specific and strong immune response against hepatocellular carcinoma cells. Liver Int 2006;26:369-379.

16. Abelev Gl, Eraiser TL. Cellular aspects of alpha-fetoprotein reexpression in tumors. Semin Cancer Biol 1999;9:95-107.

17. Kandil DH, Cooper K. Glypican-3: a novel diagnostic marker for hepatocellular carcinoma and more. Adv Anat Pathol 2009;16:125-129.

18. Zhang HM, Zhang LW, Ren J, et al. Induction of alpha-fetoproteinspecific CD4- and CD8-mediated T-cell response using RNA-transfected dendritic cells. Cell Immunol 2006;239:144-150.

19. Mizejewski GJ. Alpha-fetoprotein (AFP)-derived peptides as epitopes for hepatoma immunotherapy: a commentary. Cancer Immunol Immunother 2009;58:159-170.

20. Alisa A, Ives $A$, Pathan AA, et al. Analysis of CD4+ T-Cell responses to a novel alpha-fetoprotein-derived epitope in hepatocellular carcinoma patients. Clin Cancer Res 2005;11:6686-6694.

21. Hayashi E, Motomura $\mathrm{Y}$, Shirakawa H, et al. Detection of glypican-3specific CTLs in chronic hepatitis and liver cirrhosis. Oncol Rep 2009;22:149-154.

22. Zou W. Regulatory T cells, tumour immunity and immunotherapy. Nat Rev Immunol 2006;6:295-307.

23. Cao $M, C a b r e r a ~ R, X u ~ Y$, et al. Hepatocellular carcinoma cell supernatants increase expansion and function of CD4(+)CD25(+) regulatory T cells. Lab Invest 2007;87:582-590.

24. Kobayashi N, Hiraoka N, Yamagami W, et al. FOXP3+ regulatory T cells affect the development and progression of hepatocarcinogenesis. Clin Cancer Res 2007;13:902-911.

25. Cabrera $\mathrm{R}, \mathrm{Tu} Z, \mathrm{Xu} \mathrm{Y}$, et al. An immunomodulatory role for $\mathrm{CD} 4(+)$ CD25(+) regulatory $T$ lymphocytes in hepatitis $C$ virus infection. Hepatology 2004;40:1062-1071.

26. Hoechst B, Ormandy LA, Ballmaier $M$, et al. A new population of myeloid-derived suppressor cells in hepatocellular carcinoma patients induces CD4(+)CD25(+)Foxp3(+) T cells. Gastroenterology 2008; 135:234-243.

27. Nagaraj S, Gabrilovich DI. Myeloid-derived suppressor cells. Adv Exp Med Biol 2007;601:213-223.

28. Cheng P, Corzo CA, Luetteke N, et al. Inhibition of dendritic cell differentiation and accumulation of myeloid-derived suppressor cells in cancer is regulated by S100A9 protein. J Exp Med 2008;205:2235-2249.

29. Marigo I, Dolcetti $L$, Serafini $P$, et al. Tumor-induced tolerance and immune suppression by myeloid derived suppressor cells. Immunol Rev 2008:222:162-179.

30. Hoechst B, Voigtlaender T, Ormandy L, et al. Myeloid derived suppressor cells inhibit natural killer cells in patients with hepatocellular carcinoma via the NKp30 receptor. Hepatology 2009;50: 799-807.

31. Ko JS, Zea AH, Rini BI, et al. Sunitinib mediates reversal of myeloidderived suppressor cell accumulation in renal cell carcinoma patients. Clin Cancer Res 2009;15:2148-2157.

32. Gonzalez-Carmona MA, Lukacs-Kornek $V$, Timmerman $A$, et al. CD40ligand-expressing dendritic cells induce regression of hepato- 
cellular carcinoma by activating innate and acquired immunity in vivo. Hepatology 2008;48:157-168.

33. Patek PQ, Collins JL, Cohn M. Transformed cell lines susceptible or resistant to in vivo surveillance against tumorigenesis. Nature 1978;276:510-511.

34. Ochoa AC, Zea AH, Hernandez C, et al. Arginase, prostaglandins, and myeloid-derived suppressor cells in renal cell carcinoma. Clin Cancer Res 2007;13:721s-726s.

35. Youn Jl, Nagaraj S, Collazo $M$, et al. Subsets of myeloid-derived suppressor cells in tumor-bearing mice. J Immunol 2008;181:5791-5802.

36. Abou-Alfa GK, Schwartz L, Ricci S, et al. Phase II study of sorafenib in patients with advanced hepatocellular carcinoma. J Clin Oncol 2006;24:4293-4300.

37. Llovet JM, Bruix J. Molecular targeted therapies in hepatocellular carcinoma. Hepatology 2008;48:1312-1327.

38. Ozao-Choy J, Ma G, Kao J, et al. The novel role of tyrosine kinase inhibitor in the reversal of immune suppression and modulation of tumor microenvironment for immune-based cancer therapies. Cancer Res 2009;69:2514-2522.

39. Xin $H$, Zhang $C$, Herrmann A, et al. Sunitinib inhibition of Stat3 induces renal cell carcinoma tumor cell apoptosis and reduces immunosuppressive cells. Cancer Res 2009;69:2506-2513.

40. DuPre SA, Hunter Jr KW. Murine mammary carcinoma 4T1 induces a leukemoid reaction with splenomegaly: association with tumorderived growth factors. Exp Mol Pathol 2007:82:12-24.

41. Sato N, Michaelides MC, Wallack MK. Characterization of tumorigenicity, mortality, metastasis, and splenomegaly of two cultured murine colon lines. Cancer Res 1981;41:2267-2272.
42. Peng $\mathrm{CL}$, Guo W, Ji T, et al. Sorafenib induces growth inhibition and apoptosis in human synovial sarcoma cells via inhibiting the RAF/MEK/ ERK signaling pathway. Cancer Biol Ther 2009;8:1729-1736.

43. Curiel TJ, Coukos G, Zou L, et al. Specific recruitment of regulatory $T$ cells in ovarian carcinoma fosters immune privilege and predicts reduced survival. Nat Med 2004;10:942-949.

44. Mori $\mathrm{M}$, Ohtani $\mathrm{H}$, Naito $\mathrm{Y}$, et al. Infiltration of CD8+ T cells in non-small cell lung cancer is associated with dedifferentiation of cancer cells, but not with prognosis. Tohoku J Exp Med 2000;191:113-118.

45. Sampson JH, Archer GE, Ashley DM, et al. Subcutaneous vaccination with irradiated, cytokine-producing tumor cells stimulates CD8+ cellmediated immunity against tumors located in the 'immunologically privileged' central nervous system. Proc Natl Acad Sci USA 1996;93:10399-10404.

46. Zitvogel L, Mayordomo Jl, Tjandrawan T, et al. Therapy of murine tumors with tumor peptide-pulsed dendritic cells: dependence on $T$ cells, B7 costimulation, and T helper cell 1-associated cytokines. J Exp Med 1996;183:87-97.

47. Hanson $\mathrm{HL}$, Donermeyer $\mathrm{DL}$, Ikeda $\mathrm{H}$, et al. Eradication of established tumors by $\mathrm{CD} 8+\mathrm{T}$ cell adoptive immunotherapy. Immunity 2000;13:265-276.

48. Rosenberg SA. Progress in human tumour immunology and immunotherapy. Nature 2001;411:380-384.

49. Shrikant $P$, Mescher MF. Control of syngeneic tumor growth by activation of CD8+ T cells: efficacy is limited by migration away from the site and induction of nonresponsiveness. J Immunol 1999;162:2858-2866 